Contents lists available at Џournal IICET

JPPI (Jurnal Penelitian Pendidikan Indonesia)

ISSN: 2502-8103 (Print) ISSN: 2477-8524 (Electronic)

\title{
Pedagogical competency development of prospective special education teachers through project based learning models
}

\author{
Imam Yuwono*), Dewi Ratih Rapisa \\ Special Education Study Program, Faculty of Teacher Training and Educational Sciences, Universitas Lambung \\ Mangkurat, Indonesia
}

\begin{tabular}{l}
\hline Article Info \\
\hline Article history: \\
Received Jun $17^{\text {th }}, 2021$ \\
Revised Jul $12^{\text {th }}, 2021$ \\
Accepted Aug $25^{\text {th }}, 2021$ \\
\hline
\end{tabular}

\section{Keyword:}

Pedagogical competency Project based learning models Special education

\begin{abstract}
Prospective teachers for Children with Special Needs must have pedagogical competence in order to be able to prepare materials, determine appropriate approaches, models, methods, and learning media based on the results of the child's assessment. Efforts to build pedagogical competence in students of the Special Education study program are carried out through lectures with the Project Based Learning model based on the science learning needs possessed by each Children with Special Needs who is a student group partner in carrying out assignments. This study aims to describe the implementation of the Project Based Learning model which consists of the stages of planning, implementing, evaluating and presenting to build the pedagogic competence of students of the Special Education Study Program as prospective teachers in teaching science material to Children with Special Needs. This research was conducted by using a qualitative approach with the type of case study and using purposive sampling with the criteria of students who are taking the science learning course with special needs students. The number of samples in the study were 39 students. The results showed that lectures with a projectbased learning model through the stages of planning, implementation, presentation and evaluation were able to build students' pedagogic competence in terms of assessing children with special needs, learning assessment, modification of lesson plans, making science learning media, role-playing the modification of the lesson plans, and implementing the lesson plans that have been prepared in order to prepare Special Education students to become professional teacher candidates.
\end{abstract}

(C) 2021 The Authors. Published by IICET

This is an open access article under the CC BY-NC-SA license (https://creativecommons.org/licenses/by-nc-sa/4.0)

\section{Corresponding Author:}

Imam Yuwono,

Universitas Lambung Mangkurat,

Email: yumono54@gmail.com

\section{Introduction}

Education services for children with special needs are not limited to, Special School but are also implemented in regular schools providing inclusive education. The majority of educators who teach at special schools have a special education background so that all teachers concentrate fully on fulfilling learning for children with special needs. Different things are found in regular schools providing inclusive education which generally have fewer teachers with special education backgrounds than other disciplines. Matters related to children with special needs in inclusive schools are generally the obligations of special education teachers accompanied by more roles than regular teachers. At the elementary level, problems in implementing inclusive education can 
come from parents, teachers, students, school management, government, community and other factors. The teacher factor is caused by the lack of special education teacher, lack of teacher competence in handling children with special needs, teachers have difficulty in teaching and learning activities, lack of understanding of teachers about children with special needs and inclusive schools, heavy administrative burden, and lack of patience of teachers in dealing with children with special needs (Tarnoto, 2016).

Learning services for children with special needs are implemented based on the profile which obtained through the results of the assessment, therefore learning for children with special needs as the student center. Skills in teaching children with special needs are pedagogical competencies that must be mastered by teachers who teach and students as prospective special education teachers. According to Mulyasa (2012) in the National Education Standards Article 28 paragraph 3 point "a" it is explained that pedagogical competence is the ability to manage student learning, including understanding students, designing and implementing learning, evaluating learning outcomes, and developing students to actualize various potentials they have. Pedagogical competence must also be demonstrated by teachers with special education backgrounds who work in special schools or inclusive schools to be able to provide educational services that are in accordance with the needs of children with special needs.

Lessons in elementary school are presented thematically and based on each subject. Thematic learning generally includes Math, Natural Sciences, Social Studies, Indonesian Language, Art and Culture, Physical Education, and Civic Education. Thematic learning in special schools is generally delivered by classroom teachers, but in inclusive schools, special supervisors have the task of simplifying the delivery of subject matter to children with special needs who are accompanied so that they can learn better the material being delivered by class teachers One of the lessons in thematics that must be delivered appropriately by teachers with a special education background is science by taking into account the results of each student's assessment.

Students as prospective special education teachers are taught to master various competencies so that later they can apply their knowledge to the world of work. This is the line of the higher education administration system, which is to prepare students to become members of the community who have academic and/or professional abilities to be able to apply, develop and/or create science, technology and/or arts and can be done through a learning process that develops independent learning ability. This process is the obligation of lecturers as professional educators whose main task is to transform, develop, and disseminate knowledge. The Special Education Study Program through various courses taught aims to develop educational theory and special education, knowledge on the development of learning services based on the needs of each children with special needs. One of them is through the Children with Special Needs Natural Sciences Learning Course, students are taught to be able to develop and implement learning services based on the results of the assessment of students with special needs.

The model used in lectures to build student competence in teaching science material for children with special needs is Project Based Learning, which is a learning model or approach that focuses on concepts that involve students in problem solving through meaningful tasks (Arifa, Wibawanto, and Wirawan, 2018). The Project Based Learning model directs students (in this case students) to observe, try, propagate, and interact with other people in order to obtain information/data. This model is in accordance with the Regulation of the Minister of Education and Culture No. 66 of 2013 concerning Assessment Standards, which states that to assess skill competency can be done through a performance assessment that requires students to demonstrate a certain competency using practice tests, projects and portfolio assessments (Mahendra, 2017). The implementation of the Project Based Learning model is divided into three stages, namely planning, creating, and processing (Mahanali, 2009). The planning stage is carried out by preparing the project, including the delivery of learning objectives, real phenomena as a source of problems, motivation, organizing collaboration, and making project planning designs. The second stage, namely creating or implementing focuses on students developing ideas/ideas to create projects that will be presented in class. The processing stage is in the form of presentation and evaluation of the project findings.

This study aims to describe the implementation of the Project Based Learning model in building the pedagogical competence of prospective teachers of the Special Education Study Program in teaching science material to Children with Special Needs. Previously, several researchers had implemented Project Based Learning such as Wahyuni, Saputra, \& Harlita (2018) which examined the improvement of the oral communication skills of class X students and showed that the application of the Project Based Learning learning model could significantly improve the oral communication component of students. Yulianto, Fatchan, \& Astina (2017) researched the Application of the Lesson Study-Based Project Based Learning Model to Improve Student Learning Activity and showed that student learning activity increased from cycle I to cycle II through the Project Based Learning model based on active student Lesson Study to working on worksheets, compiling and completing project assignments with the group. In contrast to previous research, 
this study aims to describe the implementation of Project Based Learning in building the pedagogical competence of students of the Special Education Study Program as prospective teachers. Support for learning services for children with special needs requires various preparations, from various parties such as educators, learning methods, evaluation systems, learning management, infrastructure, and so on. Therefore, in order to prepare a professional teacher candidates, the students must have various competencies in order to serve the learning needs of children with special needs.

\section{Method}

The used method in this research is descriptive qualitative, which is a research method that moves on a simple qualitative approach with an inductive flow that begins with an explanatory process or event that can finally be drawn a generalization which is a conclusion from the process or event (Yuliani, 2018). The subjects in this study were students of special education study programs who took 39 students of the Children with Special Needs Natural Sciences Learning Course. The research location is in Special Schools in the cities of Banjarmasin and Martapura as well as classrooms as a place for lectures. Data collection can be done through interview techniques, questionnaires, questionnaires, observation, and a combination of the three. Data collection techniques in the study were carried out through observation, interviews, and documentation. Observations and interviews were carried out by observing and asking questions to students in delivering the work progress of the assigned tasks, while documentation was carried out through videos and reports provided.

\section{Results and Discussions}

Science learning with special needs students is a course that examines learning and learning, science learning concepts, and science learning for children with special needs (vision barriers, hearing barriers, intellectual barriers, and autism at the elementary school level). The learning outcomes of the subjects to be achieved are that students are able to display the ability to work together in groups of science learning subjects with special needs, able to display a responsible attitude towards the tasks of science learning subjects with special needs, able to build logical thinking in science learning subjects with special needs students, able to demonstrate independent and independent performance. measurable in working on the assignments for science learning subjects with special needs, able to carry out reports on the work of groups of science learning subjects with special needs, able to follow the steps of implementing science learning for children with special needs at the elementary school level, able to interpret the material presented in science learning courses children with special needs, and able to deliver material related to learning science with special needs children at the elementary school level.

The study materials in this course are learning and learning concepts, science learning concepts, and science learning for children with visual impairments, hearing impairments, intellectual disabilities, physical and motoric barriers, and autism. Efforts made by the research team in implementing study materials and to achieve Subject Learning Outcomes are by applying the Project Based Learning model with stages and targets as depicted in table 1.

The first stage, which is planning is carried out in five meetings including lecture contracts, delivery of theory by lecturers and students are instructed to conduct field studies including identification of characteristics of Children with Special Needs in the classroom and assessment of thematic learning applied by teachers. The focus of science learning leads to Biology based on the material being delivered by the teacher. When students do identification and assessment, students get a learning profile and a Children with Special Needs profile. The learning profile of Children with Special Needs consists of information about the advantages of learning, learning deficiencies, and learning needs so that the learning process becomes better. The Children with Special Needs profile contains information about children's potential, children's barriers, and learning needs so that children can master the learning material so that the focus of the problem in implementing project based learning is casuistic, that is, based on learning with children and their learning needs. These results become the basis for students to serve the learning needs of children with special needs by compiling science learning services that are in accordance with the results of the assessment. 
Table 1. Implementation of Project Based Learning in ABK Science Learning Lectures

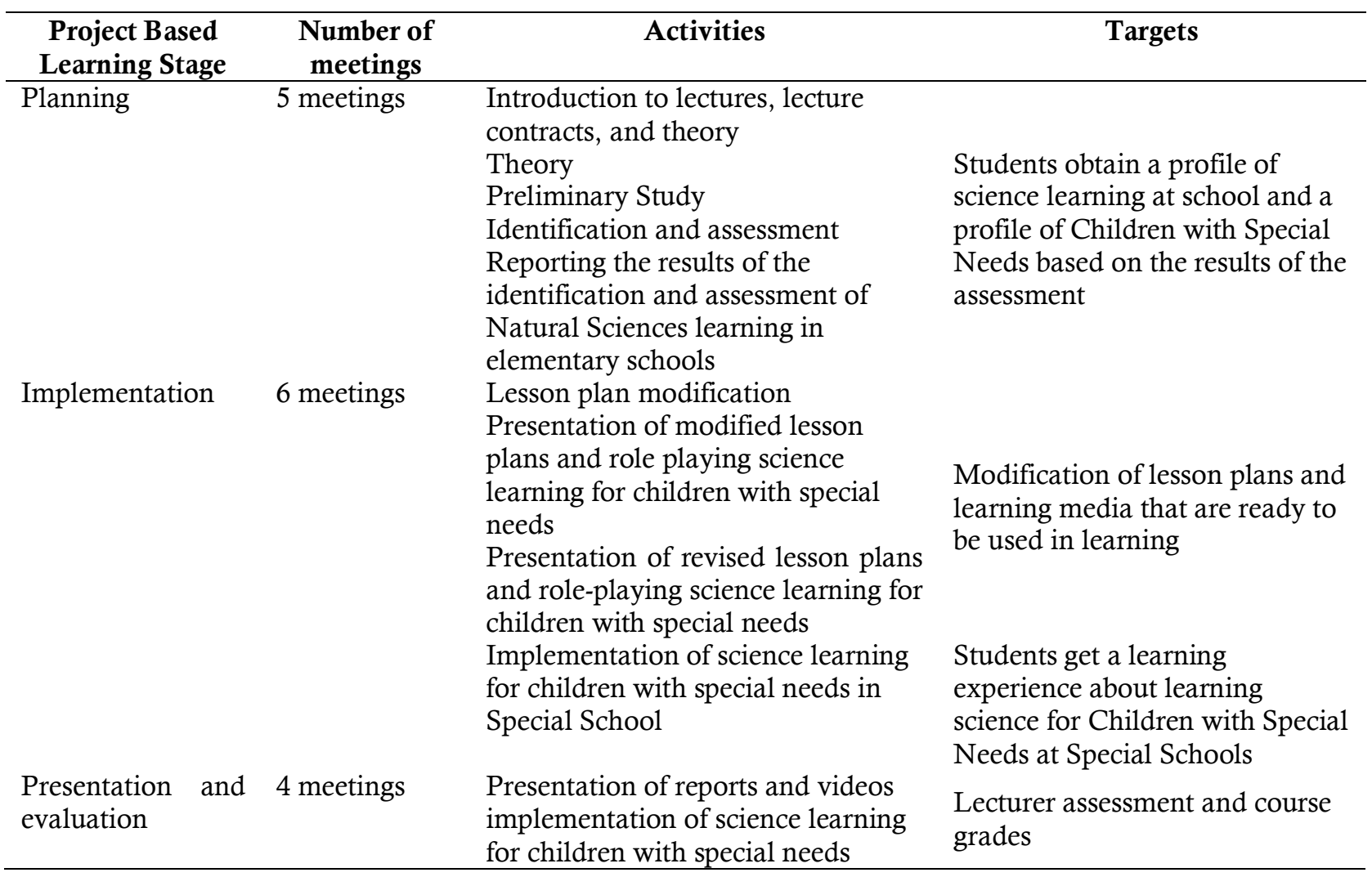

Thirty-nine students in the class were divided into six groups and the focus of science learning applied by students were:

Table 2. The focus of science learning applied by students

\begin{tabular}{|c|c|c|c|c|c|}
\hline Groups & Class & $\begin{array}{c}\text { Condition of } \\
\text { students }\end{array}$ & Subject matter & Problem finding & Study needs \\
\hline I & I & $\begin{array}{l}\text { Visual } \\
\text { impairment }\end{array}$ & $\begin{array}{l}\text { Animals in the } \\
\text { environment }\end{array}$ & $\begin{array}{l}\text { There are only a few } \\
\text { miniature animals in } \\
\text { the surrounding } \\
\text { environment available } \\
\text { in schools }\end{array}$ & $\begin{array}{l}\text { Media variations } \\
\text { so that children can } \\
\text { get to know more } \\
\text { about the variety of } \\
\text { animals in the } \\
\text { surrounding } \\
\text { environment }\end{array}$ \\
\hline II & IV & $\begin{array}{l}\text { Intellectual } \\
\text { Disability }\end{array}$ & $\begin{array}{l}\text { Butterfly } \\
\text { metamorphosis }\end{array}$ & $\begin{array}{l}\text { Submission of } \\
\text { material is not in } \\
\text { accordance with the } \\
\text { child's developmental } \\
\text { age and the media } \\
\text { used only comes from } \\
\text { pictures in books so } \\
\text { that children do not } \\
\text { fully understand the } \\
\text { material taught by the } \\
\text { teacher. }\end{array}$ & $\begin{array}{l}\text { Modification of } \\
\text { lesson plans and } \\
\text { provision of media } \\
\text { according to the } \\
\text { child's condition }\end{array}$ \\
\hline III & IV & $\begin{array}{l}\text { Intellectual } \\
\text { disability }\end{array}$ & Plant parts & $\begin{array}{l}\text { Limitations of } \\
\text { concrete learning } \\
\text { media and repetition } \\
\text { of material so that } \\
\text { children with } \\
\text { intellectual disabilities }\end{array}$ & \\
\hline
\end{tabular}




\begin{tabular}{|c|c|c|c|c|c|}
\hline Groups & Class & $\begin{array}{c}\text { Condition of } \\
\text { students }\end{array}$ & Subject matter & Problem finding & Study needs \\
\hline & & & & $\begin{array}{l}\text { can understand } \\
\text { material about plant } \\
\text { parts }\end{array}$ & \\
\hline IV & IV & $\begin{array}{l}\text { Hearing } \\
\text { impairment }\end{array}$ & Animals and plants & $\begin{array}{l}\text { Language barriers to } \\
\text { understand the } \\
\text { material presented by } \\
\text { the teacher and less } \\
\text { varied media to attract } \\
\text { children's interest in } \\
\text { learning }\end{array}$ & \\
\hline $\mathrm{V}$ & $\mathrm{V}$ & Autism & $\begin{array}{l}\text { Human respiratory } \\
\text { system }\end{array}$ & $\begin{array}{l}\text { The teacher only uses } \\
\text { the lecture method } \\
\text { and the media used is } \\
\text { only pictures on the } \\
\text { book }\end{array}$ & \\
\hline VI & II & Autism & $\begin{array}{l}\text { How to breed the } \\
\text { animals around }\end{array}$ & $\begin{array}{l}\text { Learning media does } \\
\text { not attract children's } \\
\text { interest }\end{array}$ & \\
\hline
\end{tabular}

The implementation phase is carried out in six meetings with activities in the form of students preparing modified lesson plans that focus on science learning, including developing indicators, objectives, setting learning models, learning methods, learning media, and evaluating learning aimed at children with special needs based on the material to be taught by the teacher. The modified lesson plans are then presented by the students do a role-playing science learning based on the modified lesson plans. Each student in the group has a different role, there are those who act as special needs children, regular students, and teachers. When roleplaying takes place, the science learning media that has been created are also used by student groups to determine the effectiveness of the media. After each group has demonstrated, other students are required to provide feedback and input regarding the simulation displayed. The next meeting, students submitted revisions regarding the modification of the lesson plan and improvements to learning media if there were still shortcomings in the previous meeting. The next activity is that students do science learning directly in the classroom to Children with Special Needs and it is documented through videos and the work of Children with Special Needs in the classroom.

The last stage in the implementation of the Children with special needs is Science Learning lectures which were attended by students of the Special Education Study Program was to report the results of the implementation of learning that had been implemented by submitting reports and implementation videos. On this occasion, all students in the class had the opportunity to give each other feedback on the presentations of each advanced group.

Lectures with the Project Based Learning model produce various results that are felt by lecturers and students. For course lecturers, the results achieved by students give satisfaction to the competencies that students have, namely students are able to gain knowledge about various Thematic learning conditions (especially Science) applied by Special Schools, recognize the diversity of students based on observations on the characteristics that appear in each child, adding to the assessment experience, developing lesson plans, making learning media, gaining experience teaching children with special needs, improving communication skills through conveying ideas, honing problem solving skills, and of course getting satisfactory grades for various processes in lectures that have been carried out.

Teaching readiness is a competency that must be possessed by a teacher (Arikunto, 2002). Attitudes, skills and knowledge are things that will support teachers in teaching Children with Special Needs (Wardhani, 2019). Modification of the lesson plans is one of the tasks in the Science learning course for ABK and becomes a skill in pedagogical competencies that must be possessed by prospective special education teacher students. Roza \& Rifma (2020) explained that modifications in learning tools contained in the material presented to students, learning indicators, and the media used because they had to adapt to the circumstances and needs of students, especially children with special needs. These skills were successfully achieved by students to teach science learning material contained in thematic lessons by modifying lesson plans content, for example by creating a science learning media. 
Naryono and Nuryadin (2013) said that Project Based Learning, is carried out based on constructivism learning theory which views that students build their own knowledge in the context of their own experience. The opportunity to convey ideas, listen to others, reflect on their own ideas on other people's ideas becomes an experience in individual empowerment. On the natural science learning course for children with special needs, all experiences experienced by students in lectures are outlined in a report book that is prepared procedurally and systematically based on their experience in doing assignments. The report book also contains testimonials from all group members to find out the usefulness, meaning, and effectiveness of the project based learning model. Various stages of implementation of lecture assignments aim to build student pedagogical competence based on problems and empirical learning needs of children with special needs.

Rochyadi \& Wulandari (2019) said that there were three results obtained by students through lectures with the Project Based Learning model, namely changes in attitudes in attending lectures, the ability to make products as solutions to problem solving in the field, and academic achievement. In relation to these three aspects, through lectures with a project-based learning model, students know the timeline of lectures that are carried out for one semester and the final goals to be achieved through Science Learning on Children with special needs lectures. The timeline that has been compiled becomes a reference for students to achieve the target of each lecture meeting so that all students in the group work with each other to achieve the target. Learning that is carried out jointly by all students in the group also has implications for the similarity of experiences gained through collaboration in learning by doing.

Law No. 14 of 2005 concerning Teachers and Lecturers explains that competence is a set of knowledge, skills, and behaviors that must be possessed, internalized, mastered, and actualized by teachers in carrying out professional duties. The achievement of the lecture target in building student pedagogical competencies based on the above process according to Nurbani, et al (2017) shows that lecturers with their pedagogical competencies are able to manage lectures in terms of understanding educational insights or foundations, understanding students, curriculum/syllabus development, learning design, implementation of learning, use of learning technology, Evaluation of Learning Outcomes, and student development to actualize their various potentials.

\section{Conclusions}

Based on the implementation of project based learning on students of special education study programs, three things can be obtained, namely: (1) At the planning stage, through the lecture timeline and the theory being taught, students are able to prepare for training in the form of introducing characteristics to special training participants in class. and assessing classroom teacher learning. (2) At the implementation stage, through a project-based learning model, students can prepare lesson plans that prepare materials and prepare learning media to build understanding of students with special needs. (3) At the presentation and evaluation stage, students are able to convey and report all their experiences in the form of presentations, report books, and videos. At this stage, all students in the class are also actively involved in giving feedback to each group.

The data that have been found by researchers are similar to the results of research by Rochyadi and Wulandari (2019) that the Project Based Learning model can improve understanding and skills in carrying out the learning process both in an educational environment that is ready to be disseminated to various inclusive schools as a form of community service. Another evidence regarding the effectiveness of the Project Based Learning model by Fatmawati, Ramli, and Rinanto (2014) that the Project Based Learning model applied to the Food course can improve the vocational skills of Biology education students. This research still has limitations because the implementation of Project-Based Learning used by researchers is limited to one course and only focuses on finding forms of pedagogical competence possessed by students. Based on the research process, the researcher found that the Project Based Learning model can improve other competencies that must be possessed by students, such as professional competence. The results of this study are expected to be one of the references regarding the evidence of the application of the Project Based Learning model in preparing the competence of students of the Special Education Study Program as prospective teachers for Children with Special Needs.

\section{References}

Arifa, A. B., Wibawanto, S., \& Wirawan, I Made. (2018). PENERAPAN MODEL PEMBELAJARAN PROJECT BASED LEARNING DENGAN STRATEGI METAKOGNITIF UNTUK. IV(3).

Arikunto, Suharsimi. (2002). Prosedur Penelitian, Suatu Pendekatan Praktek. Jakarta: PT Rineka Cipta.

Astina, I. K. (2017). Penerapan Model Pembelajaran Project Based Learning Berbasis Lesson Study Untuk 
Meningkatkan Keaktifan. 448-453.

Fatmawati, U., Ramli, M., \& Rinanto., Y. (2014). Penerapan Model Project-Based Learning pada Mata Kuliah Teknologi Pangan untuk Meningkatkan Vocational Skills Calon Guru Pendidikan Biologi. Jurnal Pendidikan Biologi Vol. 6 No. 1.

Mahendra, I Wayan Eka. (2017). Project Based Learning Bermuatan Etnomatematika Dalam Pembelajar. Jurnal Pendidikan Indonesia 6 (1).

Mulyasa, E. (2012). Standar Kompetensi dan sertifikasi Guru. Bandung: Remaja Rosdakarya.

Nayono, S.E., \& Nuryadin E. R.. (2013). Pengembangan Model Pembelajaran Project Based Learning. 21(1), 340347.

Nurbani, dkk. (2017). Persepsi Mahasiswa Tentang Kompetensi Pedagogik dan Kompetensi Profesional Dosen Terhadap Motivasi Belajar Mahasiswa Pada IKIP PGRI Pontianak. Jurnal Pendidikan Informatika dan Sains

Peraturan Menteri Pendidikan dan Kebudayaan No 66 Tahun 2013 tentang Standar Penilaian

Rochyadi, E., \& Wulandari, R. (2019). Project Work Model of Lectures in the Department of Special Needs Education. January 2018. https://doi.org/10.2991/indoeduc-18.2018.60.

Sugiyono. (2017). Metode Penelitian Kuantitatif, Kualitatif, dan R\&D. Bandung : CV Alfabeta.

Tarnoto, N., Psikologi, F., Dahlan, U. A., No, J. K., \& Yogyakarta, S. (n.d.). No Title. 13(1), 50-61.

Undang-Undang Republik Indonesia Nomor 14 Tahun 2005 Tentang Guru dan Dosen

Wahyuni, I. P., \& Saputra, A. (2018). Penerapan Model Pembelajaran Project Based Learning untuk Meningkatkan Keterampilan Oral Communication Peserta Didik Kelas X MIPA 4 SMA Negeri 5 Surakarta Application of Project Based Learning Learning Model to Improve Oral Communication Skills Students of Class X MIPA 4 High School 5 Surakarta. 16, 95-100.

Wardhani, M. K. (2019). Persepsi dan Kesiapan Mengajar Mahasiswa Guru Terhadap Anak Berkebutuhan Khusus dalam Konteks Sekolah Inklusi. 152-161.

Yuliani, W. (2018). Metode Penelitian Deskriptif dalam Perspektif Bimbingan dan Konseling. Quanta. 2(2), 83-91. https://doi.org/10.22460/q.v1i1p1-10.497 